\title{
PENGARUH JENIS DAN KONSENTRASI PENSTABIL PADA PEMBUATAN MINUMAN PROBIOTIK KACANG NAGARA (Vigna unguiculata ssp. Cylindrica)
}

\author{
[Effect of Type and Stabilizer Concentration on the Manufacture of Probiotik Drinks from Nagara \\ Beans (Vigna unguiculata ssp. Cylindrica)]
}

\author{
Ova Deana Sutrisno, Lya Agustina, Hisyam Musthafa Al Hakim* \\ Jurusan Teknologi Industri Pertanian Universitas Lambung Mangkurat \\ E-mail : lya.agustina@ulm.ac.id
}

Diterima 26 Agustus 2019 / Disetujui 13 November 2019

\begin{abstract}
The beans used in this study were cowpea varieties with the Latin name (Vigna unguiculata ssp. Cylindrica) that are widely known as a protein source where 100 grams of nagara beans contains 22.9 grams of protein. This study aimed to determine the effect of the type and stabilizer concentrations on the quality of probiotic drinks of nagara beans. The types of stabilizers used in this study were Carboxy Methyl Celulose (CMC) and Xanthan gum. This research was carried out using Randomized Block Design (RBD), which consisted of two factors, namely factor I Stabilizing concentrations: $0.5 \%$, 0.75\% and 1\% stabilizing factor II: CMC and xanthan gum with 3 replications, so that there were 18 times the experimental unit. Based on the SNI (2981: 2009), the best probotic drink was obtained in 1\% CMC treatment with physical quality including liquid-viscous appearance, normal/distinctive smell, sour/distinctive taste, homogeneous consistency and gray color. As well as protein content of $1.7 \%$, ash $0.1 \%$, total lactic acid $0.7 \%$, acidity level $(\mathrm{pH})$ is 3.6 and total $L A B 2.3 \times 10^{11} \mathrm{CFU} / \mathrm{m} /$.
\end{abstract}

Keywords: Nagara beans, Carboxy methyl celulose, xanthan gum, probiotic drinks

\section{ABSTRAK}

Kacang yang digunakan pada penelitian ini merupakan kacang tunggak varietas nagara dengan nama latin (Vigna unguiculata ssp. Cylindrica). Kacang-kacangan banyak dikenal sebagai sumber protein dimana per 100 gram kacang nagara mengandung protein 22,9 gram. Penelitian ini bertujuan untuk mengetahui pengaruh jenis dan konsentrasi penstabil terhadap mutu minuman probiotik kacang nagara. Jenis penstabil yang digunakan pada penelitian ini yaitu Carboxy Methyl ce/ulose (CMC) dan Xanthan gum. Penelitian ini dilakukan dengan menggunakan Rancangan Acak Kelompok (RAK), yang terdiri dari dua faktor, yaitu faktor I Konsentrasi penstabil : 0,5\%, 0,75\% dan 1\% dan faktor II jenis penstabil : CMC dan xanthan gum dengan 3 kali ulangan, sehingga didapat 18 kali satuan percobaan. Penelitian ini menghasilkan hasil terbaik yang mengacu pada SNI (2981:2009) tentang minuman probiotik yaitu pada perlakuan CMC 1\% dengan mutu fisik meliputi penampakan cair-kental, bau Normal/khas, rasa asam/khas, konsistensi homogen dan warna abu-abu. Mutu kimia kadar protein $1,7 \%$, kadar abu $0,1 \%$, total asam laktat $0,7 \%$, derajat keasaman $(\mathrm{pH}) 3,6$ dan total BAL $2,3 \times 10^{11}$ $\mathrm{CFU} / \mathrm{ml}$.

Kata Kunci: Kacang Nagara, carboxy methyl ce/ulose, xanthan gum, minuman probiotik.

\section{PENDAHULUAN}

Seiring dengan meningkatnya kesadaran masyarakat akan pentingnya pengaruh makanan dan minuman dengan manfaat fungsional bagi kesehatan, produk fermentasi berkembang dengan pesat. Salah satu contoh produk fermentasi adalah minuman probiotik. Minuman probiotik merupakan minuman yang mengandung bakteri menguntungkan bagi saluran pencernaan, umumnya bakteri asam laktat (BAL). Salah satu pangan lokal yang memiliki potensi besar untuk diolah menjadi minuman probiotik adalah kacang-kacangan. Kacangkacangan lebih banyak dikenal sebagai sumber protein. Kacang nagara memiliki banyak kandungan gizi didalamnya per 100 gram 
kacang tunggak mengandung protein 22,9 gram, lemak 1,1 gram, karbohidrat 61,6 gram dan kalsium 77,0 miligram (Poedjiadi, 2006).

Minuman probiotik akan mengendap selama proses penyimpanan sehingga diperlukan stabilizer agar minuman probiotik tidak mengalami pengendapan dan terpisah menjadi 2 fase. Stabilizer sendiri dapat digunakan untuk menstabilkan tekstur dan viskositas produk pangan dengan pembentukan gel. Pembentukan gel dapat terjadi karena kemampuan bahan penstabil berikatan dengan air. Bahan penstabil akan meningkatkan konsistensi dan stabilitas minuman probiotik. Bahan penstabil yang sering digunakan di beberapa industri pangan adalah Carboxy methyl Cellulose (CMC) dan xanthan gum.

Carboxymethyl Cellulose merupakan turunan selulosa dengan perlakuan alkali dan asam monochloro acectic atau garam sodium, yang digunakan luas dalam industri pangan (Alam et al., 2009). Ada empat sifat fungsional yang penting dari CMC yaitu untuk pengental, stabililizer, pembentuk gel dan sebagai pengemulsi. Didalam sistem emulsi hidrokoloid (CMC) tidak berfungsi sebagai pengemulsi tetapi lebih sebagai senyawa yang memberikan kestabilan. Xanthan Gum merupakan Polisakarida ekstraseluler yang disekresikan oleh mikroorganisme Xanthomonas campestris yang berasal dari kedelai atau jagung. Xanthan gum berfungsi membantu memperkuat konsistensi dari produk yang dihasilkan. Penggunaan xanthan gum biasanya pada makanan dan minuman dingin, xanthan gum membantu menciptakan tekstur lembut. Sebagai bahan stabilizer, emulsifier, and thickeners, xanthan gum banyak dimanfaatkan oleh masyarakat dalam bahan tambahan pangan maupun non pangan. Dengan demikian, dimana pemanfaatan produk olahan kacang-kacangan menjadi minuman probiotik memiliki banyak manfaat dan pentingnya stabilitas minuman probiotik yang dihasilkan maka perlu diupayakan pengaruh penambahan penstabil yang terdiri dari CMC dan xanthan gum.

\section{BAHAN DAN METODE}

\section{Bahan}

Bahan yang digunakan dalam penelitian ini adalah kacang nagara dari daerah Nagara Hulu Sungai Selatan, Carboxy Methyl Cellulose (CMC), Xanthan gum, Bakteri Lactobacillus bulgaricus, sukrosa, susu skim, MRS Broth untuk media pembuatan kultur dll.

\section{Metode}

\section{Pembuatan Starter}

Proses persiapan starter dilakukan berasarkan metode yang telah dimodifikasi (Rizal et al. 2006) yaitu kultur bakteri yang akan digunakan Lactobacillus bulgaricus diambil 1 ose secara aseptis dimasukkan kedalam masing-masing tabung reaksi berisi 5 $\mathrm{mL}$ media MRS Broth steril, selanjutnya diinkubasi menggunakan inkubator selama 48 jam pada suhu $37^{\circ} \mathrm{C}$, kultur ini disebut kultur induk. Selanjutnya dari kultur induk diinokulasikasikan ke dalam media berisi sari kacang nagara $100 \mathrm{~mL}$ dan diinkubasikan selama 48 jam pada suhu $37^{\circ} \mathrm{C}$ dan didapat kultur kerja.

\section{Pembuatan Sari Kacang Nagara}

Pembuatan sari kacang nagara menggunakan kacang yang dipilih dari daerah Nagara, kacang nagara yang akan digunakan sebelumnya dilakukan perendaman selama 24 jam kemudian ditiriskan, perendaman dilakukan untuk memudahkan proses penghalusan. Setelah ditiriskan kemudian kacang nagara di blanching selama 15 menit pada suhu $70-90^{\circ} \mathrm{C}$ kemudian dihaluskan dengan perbandingan air 6:1 dan dilakukan penyaringan hingga diperoleh sari kacang nagara.

\section{Pembuatan Minuman Probiotik Kacang Nagara dengan Bakteri Lactobacillus bulgaricus}

Minuman probiotik kacang nagara dibuat dengan menggunakan kultur Lactobacillus bulgaricus dengan memodifikasi metode yang dilakukan oleh (Agustina et al., 2010) Sari kacang nagara $250 \mathrm{~mL}$ ditambahkan dengan susu skim sebanyak $3 \%$ 
(b/v) dan penambahan sukrosa sebanyak $8 \%$ (b/v), kemudian ditambahkan masing-masing penstabil sesuai dengan rancangan percobaan kemudian di lakukan pasteurisasi pada suhu $70^{\circ} \mathrm{C}$ selama 20 menit, setelah proses pasteurisasi selanjutnay inokulasi dengan kultur Lactobacillus bulgaricus 6\% (v/v), tahap terakhir di inkubasi pada suhu $37^{\circ} \mathrm{C}$ selama 24 jam.

\section{Pengamatan}

1. Karakteristik Fisik

Karakteristik fisik pada minuman probiotik dilakukan uji skoring terhadap penampakan, bau, rasa, konsistensi dan warna dengan skala yang sudah ditetapkan.

2. Karakteristik Kimia

Pengamatan pada karakteristik kimia minuman probiotik meliputi kadar protein, kadar abu, total asam laktat dan derajat keasaman $(\mathrm{pH})($ AOAC, 1995).

Pengukuran kadar protein dengan menimbang berat sampel masing-masing $2 \mathrm{~g}$ menggunakan metode mikro kjeldahl terdiri dari tahap destruksi, destilasi dan titrasi dengan rumus :

$\operatorname{Kadar} \mathrm{N}(\%)=$

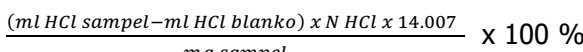

Kadar protein $(\%)=$ Kadar $\mathrm{N}(\%)$ x faktor konversi $(6,25)$

Pengukuran kadar abu dengan menimbang masing-masing berat sampel $5 \mathrm{~g}$ menggunakan tanur dengan rumus :

Kadar Abu (\%) $=\frac{(\text { Berat Akhir-Berat Cawan })}{\text { Berat Sampel }} \times 100 \%$

Pengukuran total asam laktat dengan menimbang $1 \mathrm{ml}$ setiap masing-masing sampel, pengukuran ini menggunakan metode titrasi dengan $\mathrm{NaOH} 0,1 \mathrm{~N}$ dengan rumus :

$\%$ Asam laktat $=\frac{\mathrm{ml} \mathrm{NaOH} \times \mathrm{N} \mathrm{NaOH} \times \mathrm{BM} \text { Asam Laktat }}{}$

Keterangan :

Normalitas larutan $\mathrm{NaOH}=0,1 \mathrm{~N}$

$\mathrm{BM}$ asam laktat $(\mathrm{CH} 3 \mathrm{CHOHCOOH})=90$

$\mathrm{ml}$ sampel $=10 \mathrm{ml}$

Pengukuran derajat keasaman $(\mathrm{pH})$ menggunakan $\mathrm{pH}$ meter. Sebelum dilakukan pengamatan, $\mathrm{pH}$ meter harus dikalibrasi lebih dulu dengan menggunakan larutan penyangga (buffer) 7.0. pengukuran dilakukkan dengan mencelupkan tiap elektrodanya kedalam larutan sampel dan dibiarkan beberapa saat hingga diperoleh hasil.

\section{Karaktersitik Biologi}

Karakteristik biologi yang diamati pada penelitian ini yaitu total bakteri asam laktat (BAL) dengan menggunakan metode sebar pada cawan petri. Sampel yang digunakan sebanyak $1 \mathrm{ml}$ dan di encerkan sampai $10^{8}$, selanjutnya dihitung dengan menggunakan rumus :

Total BAL $(\mathrm{CFU} / \mathrm{ml})=$ Luas Lingkaran $\times$ Jumlah koloni terhitung $\times \frac{1}{\text { Faktor pengenceran }}$

\section{Analisis Data}

Analisis data untuk karakteristik fisik (skoring) menggunakan uji Kruskal-Wallis pada taraf $5 \%$ dan selanjutnya di uji post hoc test pada taraf $5 \%$. Untuk uji karakteristik kimia dan biologi menggunakan ANOVA pada taraf $5 \%$ apabila berpengaruh nyata dilanjutkan dengan uji DMRT pada taraf $5 \%$. Hasil terbaik berdasarkan analisis data tersebut kemudian dilanjutkan dengan pengujian yang mengacu pada SNI (2981:2009).

\section{HASIL DAN PEMBAHASAN}

\section{Pengaruh Jenis dan Konsentrasi Penstabil (CMC dan xanthan gum) terhadap Mutu Fisik}

Uji skoring merupakan uji dimana panelis diminta untuk menilai berdasarkan intensitas atribut atau sifat yang menggunakan skala angka.

\section{Penampakan}

Penampakan merupakan parameter oganoleptik yang penting karena merupakan sifat sensoris pertama yang dilihat oleh konsumen. Umumnya konsumen memilih makanan dengan penampakan menarik. Hasil analisis statistik dengan menggunakan uji Kruskal-Wallis menunjukan bahwa jenis dan konsentrasi penstabil berpengaruh terhadap penampakan minuman probiotik pada taraf 
5\% dan dilanjutkan dengan uji Tukey. Hasil uji skoring (penampakan) dapat dilihat pada Tabel 1.

Tabel 1. Hasil Uji Lanjut pada Parameter Penampakan

\begin{tabular}{lc}
\hline \multicolumn{1}{c}{ Perlakuan } & Penampakan \\
\hline CMC 0,5\% & $2,8000^{\mathrm{b}}$ \\
CMC 0,75\% & $2.9500^{\mathrm{b}}$ \\
CMC $1,0 \%$ & $2.7667^{\mathrm{b}}$ \\
Xanthan gum 0,5\% & $2.1667^{\mathrm{a}}$ \\
Xanthan gum 0,75\% & $3.1833^{\mathrm{b}}$ \\
Xanthan gum 1,0\% & $4.0500^{\mathrm{c}}$ \\
\hline
\end{tabular}

Keterangan : huruf berbeda menunjukan hasil berbeda nyata antar perlakuan menurut Uji DMRT

Hasil analisis menunjukkan pada jenis pentabil xantan gum dengan konsentrasi $1 \%$ memiliki penampakan yang sesuai dengan SNI (2981:2009) yaitu cairan kental-padat. Hal ini dikarenakan kemampuan xanthan gum pada konsentrasi rendah telah memiliki viskositas yang tinggi, pada konsentrasi rendah larutannya kental dan membentuk gel yang dapat mempertahankan kekentalannya sehingga semakin banyak konsentrasi yang ditambahkan maka tingkat kekentalan akan semakin tinggi, namun pada produk minuman probiotik tidak diharapkan dengan tingkat kekentalan yang tinggi, xanthan gum ini mampu menjaga kestabilan bahan baik pada kondisi membeku ataupun cair.

\section{Bau/Aroma}

Indera pembau digunakan untuk menilai bau/aroma suatu produk pangan. Bau/aroma pada umumnya sangat subyektif serta sulit diukur, karena setiap orang mempunyai sensitifitas dan kesukaan yang berbeda (Meilgaard et al., 2000). Hasil analisis statistik dengan menggunakan uji KruskalWallis menunjukan bahwa jenis dan konsentrasi penstabil berpengaruh tidak nyata terhadap bau/aroma minuman probiotik pada taraf 5\%. Hasil uji skoring terhadap parameter bau/arom dapat dilihat pada Tabel 2 .

Berdasarkan SNI (2981: 2009) minuman probitoik yang dihasilkan memenuhi standar minuman probiotik yaitu memiliki bau yang khas/asam kecuali pada perlakuan CMC $0,5 \%$ memiliki bau asam yang sangat kuat.
Bau asam yang sangat kuat ini dipengaruhi oleh jenis dan konsentrasi penstabil yang digunakan, dimana CMC pada konsentrasi rendah tidak mampu meningkatkan kekentalan sehingga bakteri berkembang dengan baik dan meningkan bau yang merupakan senyawa volatil (mudah menguap).

Tabel 2. Hasil Uji Skoring Parameter Bau/Aroma

\begin{tabular}{lc}
\hline \multicolumn{1}{c}{ Perlakuan } & Bau/Aroma \\
\hline CMC 0,5\% & 4.0000 \\
CMC 0,75\% & 3.9167 \\
CMC 1,0\% & 3.9833 \\
Xanthan gum 0,5\% & 3.8500 \\
Xanthan gum 0,75\% & 3.8000 \\
Xanthan gum 1,0\% & 3.7500 \\
\hline
\end{tabular}

\section{Rasa}

Rasa merupakan sebagai rangsangan yang ditimbulkan oleh bahan yang dimakan. Hasil analisis statistik dengan menggunakan uji Kruska-Wallis menunjukan bahwa jenis dan konsentrasi penstabil tidak berpengaruh terhadap rasa minuman probiotik pada taraf $5 \%$. Hasil uji skoring (rasa) dapat dilihat pada Tabel 3.

Tabel 3. Hasil Uji Skoring Parameter Rasa

\begin{tabular}{lc}
\hline \multicolumn{1}{c}{ Perlakuan } & Rasa \\
\hline CMC 0,5\% & 3.7000 \\
CMC 0,75\% & 3.5667 \\
CMC $1 \%$ & 3.7333 \\
Xanthan gum 0,5\% & 3.7667 \\
Xanthan gum 0,75\% & 3.5667 \\
Xanthan gum 1\% & 3.7667 \\
\hline
\end{tabular}

Rasa yang dihasilkan masih memenuhi syarat SNI (2981 :2009) dimana minuman probiotik memiliki rasa asam/khas. Akan tetapi pada minuman prbobiotik ini masih memiliki rata-rata rasa asam yang tinggi. Menurut Prabandari (2011) rasa asam yang tinggi dikarenakan produksi asam laktat selama proses fermentasi yang lebih tinggi. Semakin tinggi konsentrasi penstabil semakin berkurang tingkat keasaman hal ini disebabkan karena asam laktat akan semakin banyak terikat oleh 
bahan penstabil sehingga minuman probiotik memiliki rasa yang tidak terlalu asam.

\section{Konsistensi}

Konsistensi adalah merupakan ciri suatu bahan sebagai akibat perpaduan dari beberapa sifat fisik yang meliputi ukuran, bentuk, jumlah dan unsur-unsur pembentukan bahan yang dapat dirasakan oleh indera peraba dan perasa, termasuk indera mulut dan penglihatan. Hasil analisis statistik dengan menggunakan uji Kruskal-Wallis menunjukan bahwa jenis dan konsentrasi penstabil berpengaruh nyata terhadap konsistensi minuman probiotik pada taraf $5 \%$ dan dilanjutkan dengan uji Tukey. Hasil uji skoring (Konsistensi) dapat dilihat pada Tabel 4.

Tabel 4. Hasil Uji Lanjut Parameter Konsistensi

\begin{tabular}{ll}
\hline \multicolumn{1}{c}{ Perlakuan } & Konsistensi \\
\hline CMC 0,5\% & $1.3000^{\mathrm{b}}$ \\
CMC 0,75\% & $1.2000^{\mathrm{ab}}$ \\
CMC $1,0 \%$ & $1.0667^{\mathrm{a}}$ \\
Xanthan gum 0,5\% & $1.2667^{\mathrm{ab}}$ \\
Xanthan gum 0,75\% & $1.2167^{\mathrm{ab}}$ \\
Xanthan gum 1,0\% & $1.0667^{\mathrm{a}}$ \\
\hline
\end{tabular}

Keterangan : huruf berbeda menunjukan hasil berbeda nyata antar perlakuan menurut uji DMRT

Berdasarkan SNI 2981: 2009 semua perlakuan memenuhi standar yang telah ditetapkan yaitu homogen. perlakuan CMC 1\% dan xanthan gum $1 \%$ memiliki penampakan yang paling homogen. Hal ini dikarenakan CMC merupakan jenis penstabil ester polimer selulosa yang larut dalam air sehingga akan mengikat air didalam sari kacang nagara dan meningkatkan tekstur minuman probiotik yang dihasilkan.. Hasil analisis konsistensi menunjukkan semakin tinggi konsentrasi penstabil yang ditambahkan maka minuman probiotik yang dihasilkan homogen. Demikian pula dengan xanthan gum yang mempunyai sifat sangat mudah larut dalam air (dingin maupun panas). Selain itu xanthan gum juga memiliki viskositas yang tinggi bahkan pada penambahan konsentrasi penstabil yang tidak terlalu tinggi (Utomo, et al., 2013).

\section{Warna}

Warna adalah atribut kualitas yang paling penting. Bersama-sama dengan penampakan, bau dan rasa, warna berperan dalam menentukan tingkat penerimaaan suatu produk. Hasil analisis statistik dengan menggunakan uji Kruskal-Wallis menunjukan bahwa jenis dan konsentrasi penstabil berpengaruh tidak nyata terhadap warna minuman probiotik pada taraf $5 \%$. Hasil uji skoring (warna) dapat dilihat pada Tabel 5.

Tabel 5. Hasil uji Skoring Parameter Warna

\begin{tabular}{ll}
\hline \multicolumn{1}{c}{ Perlakuan } & Warna \\
\hline CMC 0,5\% & 3.5667 \\
CMC 0,75\% & 3.7000 \\
CMC 1,0\% & 3.7667 \\
Xanthan gum 0,5\% & 3.6167 \\
Xanthan gum 0,75\% & 3.6667 \\
Xanthan gum 1,0\% & 3.7167 \\
\hline
\end{tabular}

Hasil dari uji skoring menunjukkan rata-rata warna yaitu cenderung abu-abu. Warna sendiri tidak mempengaruhi dari SNI, warna yang dihasilkan merupakan hasil dari penstabil yang ditambahkan, sebelum penambahan penstabil berwarna abu-abu muda yang merupakan warna dari kacang nagara. Mekanisme terbentuknya warna sendiri yaitu terbentuknya campuran bahan larut air dan bahan tidak larut air oleh bahan penstabil yang merupakan gugus hidrofobik dimana gugus ini akan mengikat bahan-bahan tidak larut air (bersifat non polar) dan gugus hidrofilik akan berikatan dengan air dan bahan larut air (bersifat polar). Jadi bahan penstabil memberikan mantel hidrofilik sehingga bahan yang bersifat non polar akan terperangkap didalam ikatan hidrofilik membentuk koloid. Sehingga didalam minuman probiotik kacang nagara, pigmen dapat bercampur dengan air dan bahan larut air seperti susu skim dan menghasilkan warna minuman probiotik (Prabandari, 2011).

\section{Pengaruh Jenis dan Konsentrasi Penstabil (CMC dan Xanthan gum) Terhadap Mutu Kimia \\ Pada mutu kimia hasil analisis statistik} menggunakan uji ANOVA apabila berpengaruh 
nyata pada taraf $5 \%$ maka dilanjutkan dengan uji DMRT pada tafar $5 \%$.

\section{Kadar Protein}

Kadar protein merupakan suatu zat gizi yang sangat penting bagi tubuh karena zat ini berfungsi sebagai bahan bakar dalam tubuh dan dapat juga dimanfaatkan sebagai zat pembangun dan pengatur dalam tubuh (Winarno, 2002). Hasil analisis statistik dengan menggunakan uji ANOVA menunjukan bahwa jenis dan konsentrasi penstabil berpengaruh tidak nyata terhadap kadar proteini minuman probiotik pada taraf $5 \%$. Kadar protein minuman probiotik dapat dilihat pada Tabel 6 .

Tabel 6. Kadar Protein minuman probiotik kacang nagara

\begin{tabular}{ll}
\hline \multicolumn{1}{c}{ Perlakuan } & \multicolumn{1}{c}{ Protein (\%) } \\
\hline CMC 0,5\% & 1.5033 \\
CMC 0,75\% & 1.6733 \\
CMC 1,0\% & 1.7100 \\
Xanthan gum 0,5\% & 1.4667 \\
Xanthan gum 0,75\% & 1.5433 \\
Xanthan gum 1,0\% & 1.5133 \\
\hline
\end{tabular}

Minuman probiotik dengan perlakuan terbaik yaitu pada CMC 1\% dengan kadar protein tertinggi sebesar $1,7 \%$. Untuk standar mutu sendiri belum memenuhi standar yaitu minimal 2,7\%. Akan tetapi pada minuman prbiotik kacang nagara ini telah melalui beberapa tahapan dan yang digunakan untuk pembuatan minuman probiotik yaitu sari dari minuman probiotik dimana sari dari minuman prbiotik sendiri memiliki kandungan protein yang rendah. Penurunan kadar protein dapat disebabkan karena jumlah kultur bakteri asam laktat yang dihasilkan. Menurut Prabandari (2011) semakin rendah jumlah bakteri kultur dalam minuman probiotik semakin berkurang kandungan proteinnya karena sebagian besar komponen penyusun mikroba adalah protein. Hal ini sejalan dengan pendapat Herastuti et al., (1994) dalam Yusmarini dan Efendi (2004) yang menyatakan bahwa protein yang terdapat pada yoghurt merupakan jumlah total dari protein bahan yang digunakan dan bakteri asam laktat yang terdapat didalamnya.
Kandungan protein bakteri berkisar antara 60$70 \%$.

Penurunan kadar protein dari kedua jenis penstabil dapat juga disebabkan pada saat proses pasteurisasi dimana suhu yang digunakan tidak bisa ditetapkan hanya pada $70^{\circ} \mathrm{C}$, dimana suhu naik turun pada $70-90^{\circ} \mathrm{C}$ dalam waktu 20 menit sehingga menyebabkan minuman probiotik mengalami denaturasi.

\section{Kadar Abu}

Kadar abu merupakan kandungan mineral yang terdapat dalam suatu bahan. Abu adalah zat anorganik sisa hasil pembakaran dari bahan organik. Semua bahan organik akan terbakar menjadi air $\mathrm{CO}_{2}$ dan $\mathrm{NH}_{3}$. Sedangkan elemen-elemen ang tertinggal adalah oksidanya. Hasil analisis statistik dengan menggunakan uji ANOVA menunjukan bahwa jenis dan konsentrasi penstabil berpengaruh tidak nyata terhadap kadar abu minuman probiotik pada taraf $5 \%$. Kadar abu minuman probiotik dapat dilihat pada Tabel 7.

Tabel 7. Kadar abu minuman probiotik kacang nagara

\begin{tabular}{ll}
\hline \multicolumn{1}{c}{ Perlakuan } & Kadar abu (\%) \\
\hline CMC 0,5\% & 0.3067 \\
CMC 0,75\% & 0.2867 \\
CMC 1,0\% & 0.1967 \\
Xanthan gum 0,5\% & 0.3000 \\
Xanthan gum 0,75\% & 0.1367 \\
Xanthan gum 1,0\% & 0.3033 \\
\hline
\end{tabular}

Kadar abu tertinggi pada jenis penstabil CMC $0,5 \%$ dan terendah pada xanthan gum $0,75 \%$. Semua perlakuan memenuhi syarat SNI (2981:2009) tentang minuman probiotik. Menurut Prabandari (2011) kandungan mineral pada CMC yaitu $0,6 \%$ lebih rendah dibandingkan dengan xanthan gum yaitu 7-12\% (Garcia, 2000). Semakin tinggi konsentrasi bahan penstabil yang ditambahkan maka kadar abu minuman probiotik juga akan menurun. Penurunan kadar abu disebabkan karena penambahan bahan penstabil mengurangi proporsi kandungan mineral minuman probiotik kacang nagara saat proses pasteurisasi, dimana kandungan mineral sari kacang nagara akan 
ikut terikat oleh bahan penstabil yang ditambahkan. Akan tetapi pada bahan penstabil xanthan gum, kadar abu yang dihasilkan cukup tinggi yaitu pada penambahan konsentrasi penstabil $0,5 \%$ dan $1 \%$ dan cenderung turun pada penambahan $0,75 \%$. Hal ini dikeranakan pada saat proses pasteurisasi suhu yang digunakan cenderung meningkat, saat suhu tinggi minuman probiotik yang dihasilkan cenderung kental menandakan minuman probiotik memiliki kandungan mineral lebih tinggi dan sebaliknya jika suhu menjadi rendah maka minuman probiotik lebih cair dan kandungan mineral lebih rendah. Kadar abu dari kacang nagara sendiri per 100 gram yaitu $3,7 \mathrm{~g}$.

\section{Total Asam Laktat}

Persen asam laktat dihitung sebagai total asam. Karena di dalam minuman probiotik, asam organik yang paling banyak dihasilkan adalah asam laktat sekaligus sebagai produk utamanya yang merupakan hasil dari fermentasi bakteri Lactobacillus bulgaricus. Hasil analisis statistik dengan menggunakan uji ANOVA menunjukan bahwa jenis dan konsentrasi penstabil berpengaruh terhadap total asam laktat minuman probiotik pada taraf $5 \%$ dan dilanjutkan dengan uji DMRT pada taraf $5 \%$. Total asam laktat minuman probiotik dapat dilihat pada Tabel 8 .

Tabel 8. Total asam laktat minuman probiotik

\begin{tabular}{ll}
\hline \multicolumn{1}{c}{ Perlakuan } & Asam Laktat (\%) \\
\hline CMC 0,5\% & $0.6133^{\mathrm{bc}}$ \\
CMC 0,75\% & $0.5700^{\mathrm{b}}$ \\
CMC 1,0\% & $0.7500^{\mathrm{c}}$ \\
Xanthan gum 0,5\% & $0.6000^{\mathrm{bc}}$ \\
Xanthan gum 0,75\% & $0.6900^{\mathrm{bc}}$ \\
Xanthan gum 1,0\% & $0.4033^{\mathrm{a}}$ \\
\hline Keterangan : huruf berbeda menunjukan hasil berbeda \\
nyata antar perlakuan menurut uji DMRT
\end{tabular}

Kadar asam laktat minuman probiotik memenuhi standar mutu SNI (2981:2009) tentang minuman probiotik yaitu $0,5-2 \%$ kecuali pada perlakuan xanthan gum $1 \%$ belum memenuhi standar minuman probiotik. Penambahan konsentrasi penstabil yang terlalu tinggi dapat menghambat proses fermentasi sehingga asam laktat yang dihasilkan juga berkurang. Xanthan gum merupakan bahan penstabil yang dapat meningkatkan kekentalan dalam produk minuman probiotik, dengan semakin tinggi kekentalan minuman probiotik maka menghambat produksi asam oleh bakteri asam laktat. Bakteri asam laktat bekerja dengan mengubah laktosa dalam sari menjadi asam laktat, sehingga semakin banyak laktosa yang diubah menjadi asam laktat maka nilai total asam juga akan semakin meningkat.

\section{Derajat Keasaman (pH)}

Nilai $\mathrm{pH}$ merupakan derajat nilai yang digunakan untuk menyatakan tingkat keasaman suatau bahan. Pada proses fermentasi bakteri asam laktat akan menghasilkan sejumlah asam laktat serta beberapa asam lain yang dapat menurunkan nilai pH. Hasil analisis statistik dengan menggunakan uji ANOVA menunjukan bahwa jenis dan konsentrasi penstabil berpengaruh terhadap derajat keasaman $(\mathrm{pH})$ minuman probiotik pada taraf $5 \%$ dan dilanjutkan dengan uji DMRT pada taraf 5\%. Derajat keasaman $(\mathrm{pH})$ minuman probiotik dapat dilihat pada Tabel 9.

Tabel 9. pH miuman probiotik kacang nagara

\begin{tabular}{ll}
\hline \multicolumn{1}{c}{ Perlakuan } & \multicolumn{1}{c}{ pH } \\
\hline CMC 0,5\% & $3.8333^{\mathrm{b}}$ \\
CMC 0,75\% & $3.7333^{\mathrm{ab}}$ \\
CMC $1,0 \%$ & $3.6333^{\mathrm{a}}$ \\
Xanthan gum 0,5\% & $3.7333^{\mathrm{ab}}$ \\
Xanthan gum 0,75\% & $3.7000^{\mathrm{ab}}$ \\
Xanthan gum 1,0\% & $3.7667^{\mathrm{ab}}$ \\
\hline
\end{tabular}

Keterangan : huruf berbeda menunjukan hasil berbeda nyata antar perlakuan menurut uji DMRT

Bakteri Lactobacillus bulgaricus merupakan bakteri yang digunakan pada penelitian ini, bakteri Lactobacillus bulgaricus sendiri menurut Republika (2006) dapat menurunkan $\mathrm{pH}$ hingga 3,5-4 sehingga minuman probiotik kacang nagar masih memenuhi standar mutu. Bakteri ini mengubah laktosa menjadi asam laktat selama proses fermentasi. Sehingga dengan bertambahnya jumlah asam laktat selama 
proses fermentasi terjadi penurunan $\mathrm{pH}$ dan minuman probiotik menjadi asam.

\section{Pengaruh Penambahan Jenis dan Konsentrasi Penstabil terhadap Total Bakteri Asam Laktat}

Bakteri asam laktat (genus

Lactobacillus) merupakan bakteri anaerob fakultatif yang dapat hidup pada berbagai habitat khususnya pada saluran pencernaan. Keberadaan bakteri ini dapat memberikan efek yang baik bagi kesehatan pencernaan. Hasil analisis statistik dengan menggunakan uji ANOVA menunjukan bahwa jenis dan konsentrasi penstabil berpengaruh terhadap total bakteri asam laktat minuman probiotik pada taraf $5 \%$ dan dilanjutkan dengan uji DMRT pada taraf $5 \%$. Total BAL minuman probiotik dapat dilihat pada Tabel 10 .

Tabel 10. Total BAL minuman probiotik kacang nagara

\begin{tabular}{lc}
\hline Perlakuan & Total BAL (CFU/ml) \\
\hline CMC 0,5\% & $2,2 \times 10^{11 \mathrm{c}}$ \\
CMC 0,75\% & $3,4 \times 10^{11 \mathrm{~d}}$ \\
CMC 1,0\% & $2,2 \times 10^{11 \mathrm{c}}$ \\
Xanthan gum 0,5\% & $1,2 \times 10^{11 \mathrm{a}}$ \\
Xanthan gum 0,75\% & $1,2 \times 10^{11 \mathrm{a}}$ \\
Xanthan gum 1,0\% & $1,7 \times 10^{11 \mathrm{~b}}$ \\
\hline
\end{tabular}

Keterangan : huruf berbeda menunjukan hasil berbeda nyata antar perlakuan menurut uji DMRT

Berdasarkan data pada Tabel
minuman probiotik memenuhi SNI (2981:2009) tentang minuman probiotik jenis yoghurt sebesar $10^{7} \mathrm{CFU} / \mathrm{ml}$. Pertumbuhan BAL dipengaruhi oleh ketersediaan nutrisi didalam sari kacang nagara, dimana sel-sel bakteri dapat tumbuh sampai jumlah maksimum didalam media sampai ketersediaan nutrisi didalam media tidak ada lagi. Menurut Nurwantoro et al., (2009) menyatakan bahwa kemampuan terbesar yang dimiliki BAL dapat mendegradasi berbagai jenis gula (nutrisi) menjadi berbagai komponen terutama asam laktat.

Menurut Winano (2002), CMC memiliki sifat merekatkan komponen pada sampel, membentuk gel pada sampel sehingga mengakibatkan penurunan $\mathrm{pH}$ melambat dan total asam laktat menurun, dimana $\mathrm{pH}$ terbentuk karena adanya fermentasi bakteri asam laktat. apabila CMC ditambahkan pada sampel minuman probiotik dengan kadar yang tinggi akan mengakibatkan total BAL menururun, begitupun sebaliknya. Hal ini sesuai dengan penelitian Alkali et al., (2008) yang menyebutkan bahwa peningkatan konsentrasi bahan penstabil yang ditambahkan dalam minuman probiotik dapat menurunkan produksi bakteri asam laktat.

Pada penelitian ini menunjukkan hal berbeda dimana terjadi kecendrungan peningkatan jumlah total BAL seiring dengan peningkatan konsentrasi penstabil kecuali pada perlakuan CMC $1 \%$ yang mengalami penurunan dari $3,4 \times 10^{11} \mathrm{CFU} / \mathrm{ml}$ (CMC $0,75 \%$ ) menjadi $2,2 \times 10^{11} \mathrm{CFU} / \mathrm{ml}$.

\section{Penentuan Hasil Terbaik}

Penentuan hasil terbaik dilakukan dengan cara membandingkan data yang didapat dengan SNI sehingga didapatkan hasil yang sesuai dan mendekati SNI 2981 :2009. Dapat dilihat pada tabulasi data analisis sebelumnya pada Tabel 11 .

Tabel 11. Tabulasi data mutu fisisk, kimia dan biologi

\begin{tabular}{|c|c|c|c|c|c|c|}
\hline \multirow{2}{*}{ Perlakuan } & \multicolumn{3}{|c|}{ Mutu Fisisk } & \multicolumn{2}{|c|}{ Mutu Kimia } & 10 \\
\hline & 12 & 34 & 5 & 578 & 9 & \\
\hline CMC 0,5\% & & $\sqrt{ }$ & Abu-abu tua & $\sqrt{ }$ & 3,8 & $\sqrt{ }$ \\
\hline CMC $0,75 \%$ & & $/ \sqrt{ }$ & Abu-abu tua & $\sqrt{ } \sqrt{ }$ & 3,7 & $\sqrt{ }$ \\
\hline CMC $1,0 \%$ & & $/ \sqrt{ } \sqrt{ }$ & Abu-abu tua & $\sqrt{ } \sqrt{ }$ & 3,6 & $\sqrt{ }$ \\
\hline Xanthan gum $0,5 \%$ & & $/ \sqrt{ }$ & Abu-abu tua & $\sqrt{ } \sqrt{ }$ & 3,7 & $\sqrt{ }$ \\
\hline Xanthan gum $0,75 \%$ & $\sqrt{ }$ & $/ \sqrt{ }$ & Abu-abu tua & $\sqrt{ } \sqrt{ }$ & 3,7 & $\sqrt{ }$ \\
\hline Xanthan gum $1,0 \%$ & $v v$ & $\sqrt{ } \sqrt{ }$ & Abu-abu tua & $\sqrt{ } \sqrt{ }$ & 3,7 & $\sqrt{ }$ \\
\hline
\end{tabular}

Keterangan: 1: Penampakan; 2: Bau; 3: Rasa; 4: Konsistensi; 5: Warna; 6: Kadar Protein; 7: Kadar Abu; 8: Total Asam; 9 : pH; 10: Total BAL; V: Memenuhi SNI ( $2981: 2009$ ) 
Versi Online:

http://www.profood.unram.ac.id/index.php/profood e-ISSN: 2443-3446

Dari hasil pengujian didapatkan data perlakuan terbaik berdasarkan SNI 2981 : 2009 dari aspek uji mutu fisik, kimia dan biologi yaitu CMC 1\%. Nilai rata-rata CMC 1\% dibandingkan dengan SNI 2981 : 2009 dapat dilihat pada Tabel 12.
Pro Food (Jurnal Ilmu dan Teknologi Pangan) Vol 5 No. 2 November 2019 ISSN: 2443-1095

Hasil terbaik berdasarkan uji mutu fisik, kimia dan biologi (total BAL) dilakukan uji lanjut yang meliputi uji total padatan, cemaran logam dan cemaran mikroba. Hasil yang diperoleh secara lengkap dapat dilihat pada Tabel 13.

Tabel 12. Perbandingan hasil terbaik dari perlakuan CMC 1\% dan SNI (2981 : 2009)

\begin{tabular}{lcll}
\hline \multicolumn{1}{c}{ Perlakuan } & Terbaik & \multicolumn{1}{c}{ Keterangan } & \multicolumn{1}{c}{ SNI } \\
\hline Penampakan & 2,7 & Cair-Kental & Cairan kental-padat \\
Bau & 3,9 & Normal-kuat & Normal/Khas \\
Rasa & 3,7 & Normal-Asam & Asam/Khas \\
Konsistensi & 1,0 & Homogen & Homogen \\
Warna & 3,7 & Abu muda - abu & - \\
Kadar Protein & 1,7 & $\%$ & Min 2,7\% \\
Kadar Abu & 0,1 & $\%$ & Maks. $1 \%$ \\
pH & 3,6 & - & $3,5-4$ \\
Keasaman & 0,7 & $\%$ & $0,5-2 \%$ \\
(Asam Laktat) & & & \\
Total Bakteri & $2,2 \times 10^{11}$ & CFU/ml & Min $10^{7} \mathrm{CFU} / \mathrm{ml}$ \\
asam Laktat & & & \\
\hline
\end{tabular}

Tabel 13. Uji Lanjut Berdasarkan SNI (2981 : 2009)

\begin{tabular}{|c|c|c|c|c|}
\hline No. & Kriteria Uji & Satuan & $\begin{array}{c}\text { SNI } \\
(2981: 2009)\end{array}$ & $\begin{array}{c}\text { Minuman } \\
\text { Probiotk }\end{array}$ \\
\hline 1. & Keadaan & - & & \\
\hline 1.1 & Penampakan & - & $\begin{array}{l}\text { Cairan kental- } \\
\text { Padat }\end{array}$ & Cair-Kental \\
\hline 1.2 & Bau & - & Normal/Khas & Normal-Kuat \\
\hline 1.3 & Rasa & - & Asam/Khas & Normal-Asam \\
\hline 1.4 & Konsistensi & - & Homogen & Homogen \\
\hline 2. & Kadar Lemak (b/b) & $\%$ & $0.6-2.9$ & 0.79 \\
\hline 3. & Total Padatan (b/b) & $\%$ & Min. 8.2 & 0.9 \\
\hline 4. & Protein & $\%$ & Min. 2.7 & 1.7 \\
\hline 5. & Kadar abu & $\%$ & Maks 1.0 & 0.1 \\
\hline 6. & Asam laktat & $\%$ & $0.5-2.0$ & 0.7 \\
\hline 7. & Cemaran logam & & & \\
\hline 7.1 & Timbal $(\mathrm{Pb})$ & $\mathrm{Mg} / \mathrm{g}$ & Maks. 0.3 & $<0.001$ \\
\hline 7.2 & Tembaga (Cu) & $\mathrm{Mg} / \mathrm{g}$ & Maks. 20.0 & $<0.007$ \\
\hline 7.3 & Timah (Sn) & $\mathrm{Mg} / \mathrm{g}$ & Maks. 40.0 & $<0.001$ \\
\hline 7.4 & Raksa $(\mathrm{Hg})$ & $\mathrm{Mg} / \mathrm{g}$ & Maks. 0.03 & $<0.00004$ \\
\hline 8. & Arsen (As) & $\mathrm{Mg} / \mathrm{g}$ & Maks. 0.1 & $<0.0003$ \\
\hline 9. & Cemaran Mikroba & & & \\
\hline 9.1 & Bakteri coliform & $\mathrm{CFU} / \mathrm{ml}$ & Maks. 10 & $<1.0 \times 10^{\circ}$ \\
\hline 9.2 & Salmonella & - & Negatif/ $25.5 \mathrm{~g}$ & Negatif \\
\hline 10 & Jumlah bakteri starter & $\mathrm{CFU} / \mathrm{ml}$ & Min. $10^{7}$ & $10^{11}$ \\
\hline
\end{tabular}


Versi Online:

http://www.profood.unram.ac.id/index.php/profood e-ISSN: 2443-3446

Hasil uji yang mengacu pada SNI (2981:2009) menunjukkan bahwa minuman probiotik yang dihasilkan memenuhi standar SNI kecuali pada penampakan, total padatan dan kadar protein. Penampakan yang dihasilkan menurut SNI yaitu cairan kentalpadat namun untuk minuman probiotik sari kacang nagara yang dihasilkan tidak diharapkan cairan kental-padat, sedangkan total padatan yang dihasilkan pada perlakuan CMC 1\% menunjukkan kurang dari SNI hal ini dikarenakan minuman probiotik cenderung memiliki penampakan cairan-kental sehingga padatan dari minuman probiotik menjadi rendah. Penurunan kadar protein dapat disebabkan karena jumlah kultur bakteri asam laktat yang dihasilkan. Menurut Prabandari (2011) semakin rendah jumlah bakteri kultur dalam minuman probiotik semakin berkurang kandungan proteinnya karena sebagian besar komponen penyusun mikroba adalah protein.

\section{KESIMPULAN}

Kesimpulan yang didapat dari penelitian pengaruh jenis dan konsentrasi penstabil pada pembuatan minuman probiotik kacang nagara adalah sebagai berikut:

1. Jenis dan konsentrasi penstabil yang ditambahkan pada pembuatan minuman probiotik berpengaruh nyata terhadap penampakan, konsistensi, $\mathrm{pH}$, total asam laktat dan total bakteri asam laktat.

2. Hasil terbaik berdasarkan uji mutu fisik (skoring), mutu kimia dan total BAL yaitu pada perlakuan penambahan CMC $1 \%$ yang kemudian dilakukan uji lanjut terhadap parameter cemaran logam, cemaran mikroba, total padatan dan kadar lemak yang mengacu SNI (2981 : 2009).

3. Pada perlakuan CMC $1 \%$ memenuhi standar minuman probiotik standar mutu secara keseluruhan SNI (2981: 2009) kecuali pada penampakan, total padatan dan kadar protein.
Pro Food (Jurnal Ilmu dan Teknologi Pangan) Vol 5 No. 2 November 2019

ISSN: 2443-1095

\section{UCAPAN TERIMAKASIH}

Penulis berterimakasih atas semua bantuan pihak terkait yakni kedua orang tua penulis, dosen pembimbing dan teman-teman TIP 15 yang telah membantu selama penelitian.

\section{DAFTAR PUSTAKA}

Agustina. W, Y. Andriana. 2009. Karakteristik Yoghurt Susu Nabati Kacang Hijau (Phaseolus radiatus L.). Balai Besar pengembangan Teknologi Tepat Guna. LIPI. Bandung.

Alam, M.D.K., M. Ahmed, S. Akter, N. Islam, J.B. Eun. 2009. Effect of Carboxy Methyl Cellulose and Starch as Thickening Agents on the Quality of Tomato Ketchup. Pakistan Journal of Nutritio. Vol 8: 1144-1149.

Alkali J.S, T.M. Okonkwo, E.M. Lordye. 2008. Effects of stabilizer on the physicchemical attributes of thermized yoghurt. African Journal of Biotechnology. 7(2): 158-163.

AOAC. 1995. Official Methods of Analysis of The Association of Analytical Chemists. Washington D.C.

Garcia, M.A., M.N. Martino, N.E. Zaritzky. 2000. Lipid addition to improve barrier properties of edible starchbased film and coating. Jurnal Food and Science. 65(6): 941-947.

Herastuti S.R, Sujiman R.S. dan Ningsih N. 1994. Pembuatan Pati Guide (Cajanus cajan L.) dan Pemanfaatan Hasil Sampingnya dalam Pembuatan Yoghurt dan Tahu. Laporan Hasil Penelitian. FP Universitas Jenderal Sudirman. Purwokerto.

Nurwantoro, Sutaryo, D. Hartanti, H. Sukoco. 2009. Viabilitas Bifidobacterium bifidum, kadar laktosa dan rasa es krim simbiotik pada lama penyimpanan suhu beku yang berbeda. Agric. 34(1): 16-21.

Meilgaard, M., G.V. Civille., B.T. Carr. 2000. Sensory Evaluation Techniques. Boca Raton, Florida: CRC Press.

Prabandari, W. 2011. Pengaruh Penambahan berbagai jenis bahan penstabil terhadap karakteristik fisikokimia dan 
Versi Online:

http://www.profood.unram.ac.id/index.php/profood e-ISSN: 2443-3446

organoleptik yoghurt jagung. Skripsi. Fakultas Pertanian. Universitas Sebelas Maret. Surakarta.

Poedjiadi, A. 2006. Dasar-Dasar Biokimia. UI Press. Jakarta. Indonesia.

Republika. 2006. Pangan Harus Aman Bermutu dan Bergizi. Bharata Karya Aksara. Jakarta. Indonesia

Rizal, S., S. Udayana, Marniza. 2007. Pengaruh Penambahan Glukosa dan Skim pada Pembuatan Minuman Laktat Sari Kulit Nanas yang Difermentasi oleh Lactobacillus acidophillus. Jurnal AGRITEK. 15(1): 0852-5426.

Standar Nasional Indonesia. No. 01-29811992. Yogurt. Pusat Standarisasi
Pro Food (Jurnal Ilmu dan Teknologi Pangan)

Vol 5 No. 2 November 2019

ISSN: 2443-1095

Industri. Departemen Perindustrian dan Perdagangan. Jakarta. Indonesia.

Utomo M.S., Purwadi, I. Thohari. 2013. Pengaruh Tepung Porang (Amorphophallus oncophyllus) terhadap Kualitas Yoghurt Drink Selama Penyimpanan pada Refrigerator Ditinjau dari TPC, Viskositas, Sineresis dan pH. Skripsi. Fakultas Peternakan. Universitas Brawijaya. Malang.

Winarno, F. G. 2002. Kimia Pangan dan Gizi. Jakarta: PT Gramedia Pustaka Utama.

Yusmarini dan Efendi, R. 2004. Evalusi Mutu Soyghurt yang Dibuat dengan Penambahan Beberapa Jenis Gula. Universitas Riau. Pekanbaru. Jurnal Natur Indonesia. Vol 2: 104-110 